\title{
REVIEW
}

\section{Using skeletal muscle as an artificial endocrine tissue}

\author{
G S MacColl ${ }^{1,2}$, G Goldspink ${ }^{2}$ and P M G Bouloux ${ }^{1}$ \\ ${ }^{1}$ Centre for Neuroendocrinology, Royal Free Hospital School of Medicine, Rowland Hill Street, London NW3 2PF, UK \\ ${ }^{2}$ Department of Anatomy and Developmental Biology, Royal Free Hospital School of Medicine, Rowland Hill Street, London NW3 2PF, UK \\ (Requests for offprints should be addressed to G S MacColl, Department of Anatomy and Developmental Biology, Royal Free Hospital School of Medicine, \\ Rowland Hill Street, London NW3 2PF, UK)
}

\begin{abstract}
Gene transfer into muscle tissue is currently being developed as a method for the production, secretion and delivery of therapeutic proteins. This methodology has been used to produce a variety of physiologically active proteins and may ultimately be applied to the treatment of several diseases. In this review, we consider several applications of this methodology and discuss approaches for
\end{abstract}

modulating therapeutic protein production and secretion from muscle, using growth hormone as an example. In addition, factors limiting the effectiveness of muscle gene transfer are also discussed, as these shall determine the efficacy of muscle gene transfer when applied to humans. Journal of Endocrinology (1999) 162, 1-9

\section{Introduction}

The use of skeletal muscle for producing therapeutic proteins following muscle gene transfer (MGT) is a rapidly developing area of gene therapy. In the past 8 years, MGT has progressed from the expression of bacterial reporter genes (Wolff et al. 1990), to the production of hormones (Tripathy et al. 1994) and neurotrophic factors (Haase et al. 1996). This remarkable property of muscle, for producing many different types of protein, has led to its systematic evaluation and while the application of MGT appears promising, little is yet known about medium to long-term safety. In addition, it is important to develop techniques for regulating therapeutic gene expression in muscle tissue, as the controlled release of protein will be a requirement for many clinical applications. Although several of the proteins described in the following sections are not classical hormones, their production in muscle serves as a useful paradigm for secreted proteins in general. This review evaluates the key factors affecting the efficacy and safety of MGT.

Why use muscle for gene transfer?

Several factors make skeletal muscle an attractive site for therapeutic gene expression. First, it is an abundant tissue, making up about $40 \%$ of the average adult's body mass and secondly, it is accessible to most of the delivery methods currently used in gene therapy. There is no significant cell replacement in skeletal muscle tissue (Fischman 1972) and the introduced genes are not constantly lost following mitosis. This results in durable therapeutic protein production in muscle (Yao et al. 1991, Danko \& Wolff 1994, Tripathy et al. 1994).

In addition to skeletal muscle, smooth (Feldman et al. 1996) and cardiac muscle tissue (Rothmann et al. 1996) are also being investigated as potential sites for therapeutic gene expression, where local delivery of protein is often desirable.

\section{Gene transfer methods}

Therapeutic genes are delivered by injection into muscle tissue using several different types of vector, the choice of which depends on the specific application (Gorecki \& MacDermot 1997, Vile et al. 1998) (Fig. 1). Recombinant viral vectors derived from human adenoviruses and adenoassociated viruses $(\mathrm{AAV}) /$ parvoviruses are frequently used for MGT because of their capacity for transfecting large numbers of muscle fibres. However, for the purpose of safety, viral vectors are modified by removal of immunogenic sequences and the regulatory sequences essential for replication (Yang et al. 1996, Fisher et al. 1997, Yeh \& Perricaudet 1997).

Plasmid DNA-based vectors are used for MGT, as these also transfect significant numbers of muscle fibres following intramuscular injection (Davis et al. 1993). The efficiency of plasmid DNA uptake by muscle cells can 


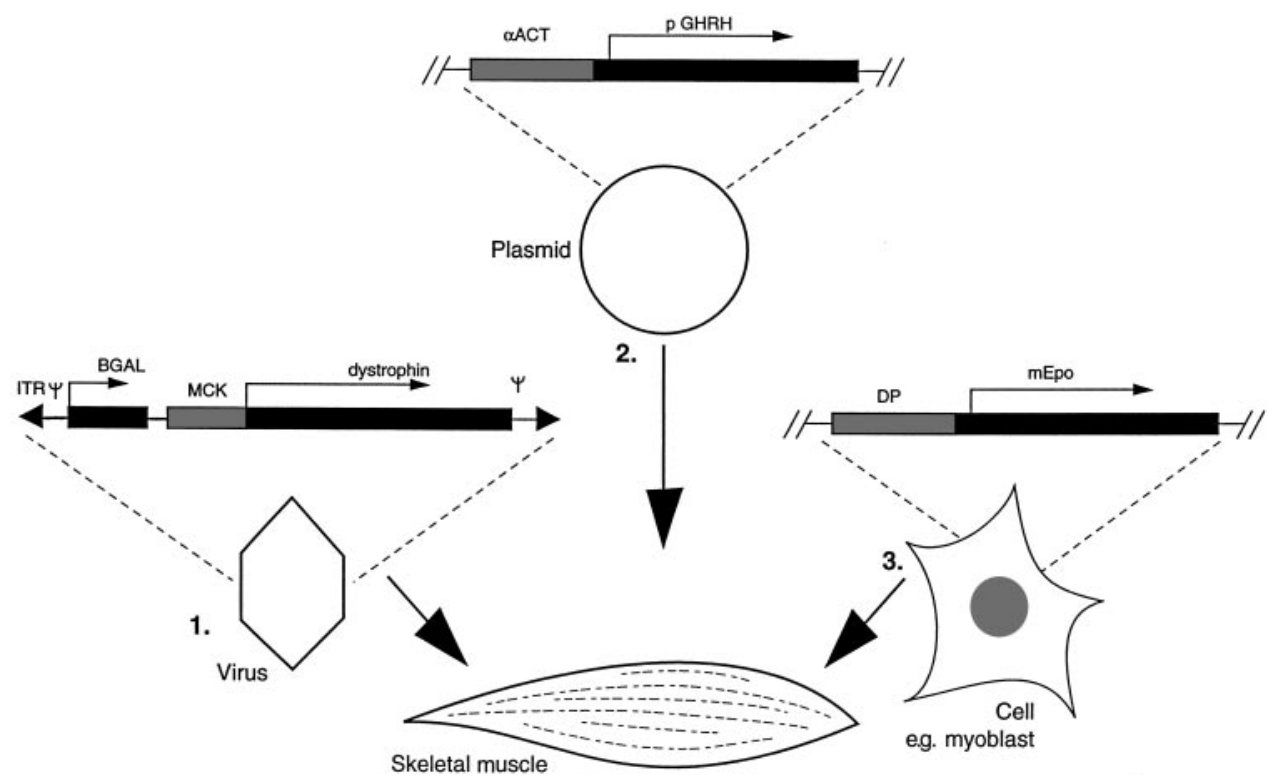

Figure 1 Three types of muscle gene delivery vector. Step 1. Viral vectors with deletion of all viral protein coding sequences, e.g. adenovirus encoded dystrophin. ITR - terminal repeat, $\Psi$-packaging signal, BGAL E. coli lacZ reporter gene controlled by human cytomegalovirus promoter, MCK - muscle creatine kinase promoter controlling dystrophin cDNA expression (Kochanek et al. 1996). Step 2. Plasmid gene transfer, e.g. plasmid encoded growth hormone-releasing hormone (pGHRH), $\alpha \mathrm{ACT}$ - skeletal alpha actin promoter (Draghiaakli et al. 1997). Step 3. Cell based gene transfer into muscle, e.g. myoblasts encoding murine erythropoietin (mEpo) cDNA, DP - doxycycline inducable promoter (Bohl et al. 1997).

further be increased by combining these DNA molecules with synthetic polymers such as liposomes (Gregoriadis et al. 1997) or polyvinyl derivatives (Mumper et al. 1998). In addition, other novel methods such as in vivo electroporation have been shown to increase both the number of muscle fibres taking up DNA and the plasmid copy number within these fibres (Aihara \& Miyazaki 1998). In common with viral vectors, expression of plasmid encoded cDNA is driven using either viral or other eukaryotic transcription elements (Wang et al. 1996, Novo et al. 1997) (Fig. 1).

A third method for introducing genes into muscle tissue uses genetically modified myoblasts or fibroblasts. Myoblasts are muscle progenitor cells which differentiate to form the multinucleated myotubes found in muscle tissue and these will stably produce a therapeutic protein once incorporated into new muscle fibres. In addition, cells can be genetically modified to express a variety of different genes and this enables a more precise control of therapeutic gene expression (Rivera et al. 1996, Bohl et al. 1997) (Fig. 2). However, implanted myoblasts and fibroblasts have to be autologous, or the recipient must be given immunosuppressants to prevent rejection of these cells (Pin \& Merrifield 1997).

\section{Evaluation of therapeutic gene expression in vitro}

Myoblasts can also differentiate into myotubes in tissue culture and these multinucleated cells express many of the genes which are active in mature muscle fibres. Thus, effective combinations of transcription elements for driving therapeutic gene expression can be determined first in vitro (Novo et al. 1997). This methodology is also used to confirm that the expressed protein has an appropriate biological activity prior to any in vivo study (Tripathy et al. 1994, MacColl et al. 1998).

\section{Applications of gene transfer in muscle}

Following the evaluation of therapeutic gene expression in vitro, MGT can then be applied to an appropriate experimental animal model for the disease being studied. Several of these key in vivo studies are discussed below.

\section{Erythropoietin insufficiency}

The production of the haemopoietic factor, erythropoietin (Epo), in muscle tissue has been suggested as an alternative to the frequent doses of recombinant Epo required to treat severe anaemias resulting from renal failure in humans (Tripathy et al. 1994). In mice, both serum Epo levels and haematocrit can be raised by MGT of Epo coding sequence and the dose of Epo produced in muscle tissue is dependent on the amount of vector used. It is also significant that serum Epo levels remain elevated for several months, indicating that the delivery vector is maintained in the muscle tissue for this time. However, 
(a)

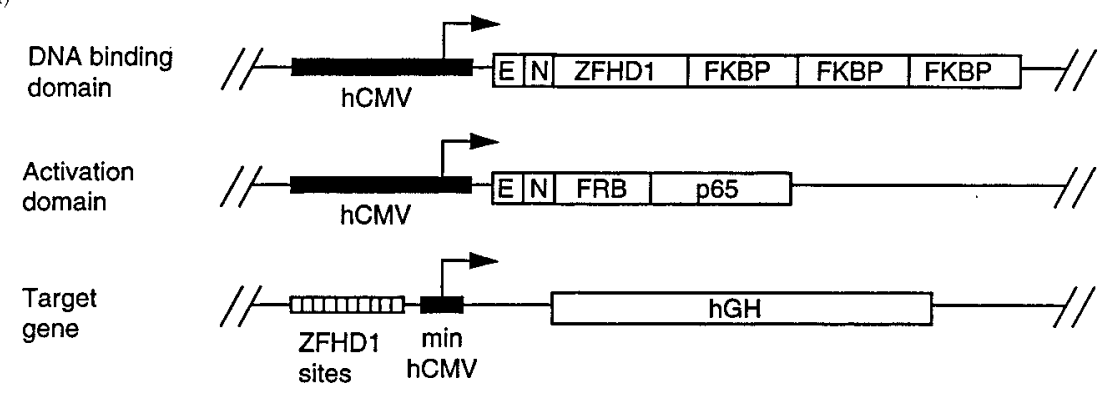

(b)

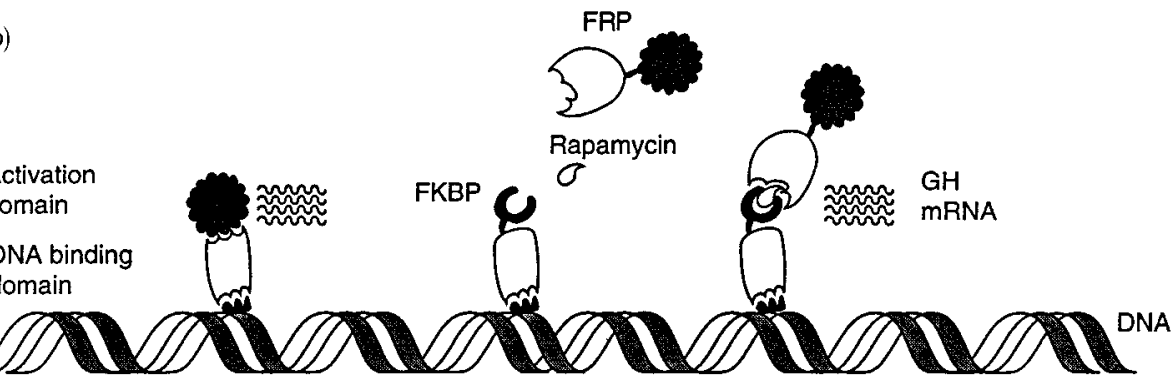

Transcription

factor
Separate DNA-binding and activation domains
Artificially clustered transcription complex

(c)

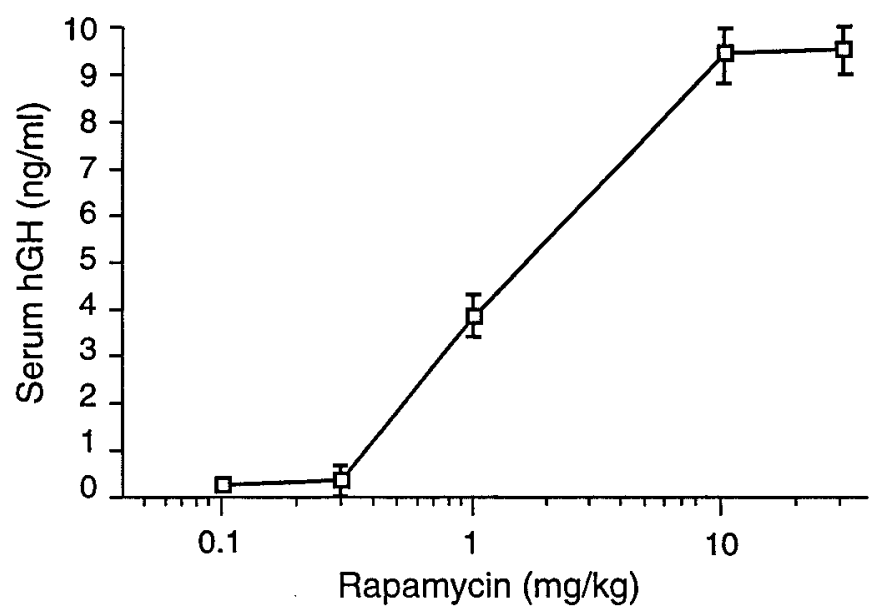

Figure 2 Regulated GH production in muscle. (a) DNA sequences for expression of human $\mathrm{GH}(\mathrm{hGH})$ cDNA in human fibrosarcoma cells. DNA binding domain: hCMV - human cytomegalovirus immediate early promoter, E - epitope tag, N - SV40 viral T antigen nuclear localisation sequence, composite of ZFHD1 DNA binding domain with FKBP. Activation domain: FRP and transcription activation domain of p65. Target gene: ZFHD1/min hCMV - tandem ZFHD1 DNA binding sites/minimal CMV promoter for hGH expression. (b) Formation of FRP-rapamycin-FKBP tripartite complex, activation of hGH transcription. (c) Dose-dependent release of hGH into the serum following administration of rapamycin to nude mice implanted with engineered human fibrosarcoma cells. Values are expressed as means \pm S.E.M. (from Rivera et al. 1996, with permission from Nature Medicine). 
the Epo levels observed in these studies were higher than those normally observed under physiological conditions and a persistently high level of haematocrit would not be desirable in humans. Therefore, the production of Epo must be regulated, as under normal physiological conditions an oxygen deficit increases Epo mRNA levels, with subsequent increases in serum Epo levels stimulating erythrocyte production (McGary et al. 1997). Methods for regulating Epo gene expression in muscle are discussed in more detail later in this review.

\section{Glomerulonephritis}

An overproduction of transforming growth factor beta (TGF $\beta$ ) in the kidney has been associated with the abnormal glomerular matrix deposition occurring during nephritic disease. TGF $\beta$ activity can be inhibited by the glycoprotein, decorin (Yamaguchi et al. 1990), and kidney fibrosis and proteinuria resulting from glomerulonephritis in rats has been attenuated following MGT of a sequence encoding decorin (Isaka et al. 1996). Although these results are promising, TGF $\beta$ also affects other important physiological activities such as wound healing (Border \& Noble 1995, Sporn \& Roberts 1992) and a general inhibition of TGF $\beta$ activity by decorin could interfere with these processes. Therefore this proposed treatment for nephritic disease using decorin currently lacks the necessary specificity.

\section{Diabetic neuropathy}

Recent studies in both animals and humans demonstrate that neurotrophic factors such as nerve growth factor (NGF) (Rask et al. 1998) and insulin-like growth factor (IGF) (Ishii \& Lupien 1995, Apfel \& Kessler 1996) can reverse the peripheral neuropathy that is associated with diabetes. MGT of IGF-I coding sequence has been used to reduce the progressive motor neuropathy observed in diabetic mice, as a 4-week treatment using plasmid encoded IGF-I increased nerve and muscle activity to the level of non diabetic controls (Coleman et al. 1998).

\section{Motor neurone disease}

The effects of IGF-I on diabetic neuropathy following MGT suggest that this method could be applied to the treatment of other diseases where severe neural damage occurs. Motor neurone disease (MND) represents a complex group of neurodegenerative diseases which may respond to this approach. A reduction in neurone degeneration, increased innervation, improved motor responses and a significant increase in survival rate were all observed, following MGT of ciliary neurotrophic factor (CNTF) and neurotrophin-3 (NT-3) coding sequences in a murine model of the amyotrophic lateral sclerosis (ALS) variant of MND (Haase et al. 1996).
As clinical trials for ALS using recombinant human CNTF protein have so far been unsuccessful due to the poor bioavailability of this factor (Cedarbaum et al. 1995), MGT directed expression of CNTF could be used to increase the clinical efficacy of this protein in ALS patients; by directing CNTF expression to the neurones where it is normally produced.

\section{Peripheral vascular disease}

MGT could have a significant clinical impact in treating the peripheral vascular diseases which can cause limb ischaemia (Lepantalo \& Tukianen 1996). Several studies using animal models for limb ischaemia have demonstrated a positive response to treatment with plasmid encoded vascular endothelial growth factor (pVEGF), a factor which stimulates angiogenesis in muscle tissue (Battegay 1995). MGT of pVEGF into the ischaemic limb caused an increase in capillary density and blood flow (Takeshita et al. 1994), suggesting a potential for its application in humans with an advanced disease, where conventional vascularisation is not possible.

However, VEGF is also produced by some types of tumour cell and it inhibits the maturation of dendritic cells (Gabrilovich et al. 1996). Inadequate tumour antigen presentation by dendritic cells has been suggested as a potential mechanism for tumour cell immune evasion (Oyama et al. 1998). Therefore, the role of this factor in the pathogenesis of cancer must be considered as a potential side effect if VEGF is to be applied to the treatment of peripheral vascular disease.

\section{Single enzymatic defects - Fabry disease}

Therapeutic protein can be released constantly following MGT, if promoter elements with continuous activity are used. Patients with systemic diseases requiring expensive enzyme replacement therapy may benefit from this type of protein delivery. For instance, Anderson-Fabry lysosomal storage disease is one such disorder for which MGT is being developed. The inherited $\alpha$-galactosidase A $(\alpha-$ GAL $)$ deficiency causing Fabry disease results in a widespread accumulation of its glycosphingolipid substrate in most tissues and body fluids and, although enzyme replacement therapy reduces levels of accumulated serum glycosphingolipids, purified human $\alpha-G A L$ is only available in very limited quantities at present (Desnick \& Bishop 1995). Recent studies indicate that muscle can produce significant quantities of this enzyme, as Fabry patient fibroblasts take up $\alpha$-GAL secreted from muscle cells transfected $\alpha$-GAL coding sequence via its native endocytic pathway (Novo et al. 1997). In addition, a more complete model for the treatment of Fabry disease by MGT can now be investigated, with the recent generation of an $\alpha-G A L$ deficient transgenic mouse (Ohshima et al. 1996). 


\section{$D N A$ vaccines}

The final example of MGT describes the development of DNA vaccines and this is currently one of the most intensively studied areas of MGT. DNA vaccines are designed to produce antigens within muscle tissue and, subsequently, antigen production stimulates both cellular and humoral immune responses to pathogenic infections (Waine \& McManus 1995). Thus MGT has been used to generate protective immunity against diverse pathogens such as Mycoplasma pneumoniae (Barry et al. 1995) and Hepatitis B (Davis et al. 1996).

DNA vaccines can also stimulate a stronger cell mediated $\mathrm{T}$ helper 1 (Th1) based immune response than some conventional vaccines (Roman et al. 1997). Another novel application of this methodology is the development of vaccines directed against pathogens which evade immunological neutralisation by antigenic variation; DNA vaccines have been designed to encode several thousands of antigen subunits (Barry et al. 1995) and this type of vaccination strategy could be directed against pathogens such as the malarial parasite, Plasmodium falciparum.

\section{Regulation of gene expression in muscle}

The gene transfer protocols discussed above are designed for continuous release of protein after MGT and, although this may be potentially useful in treating systemic disorders such as Fabry disease, which require a regular supply of a-GAL (Novo et al. 1997), this type of delivery may cause side effects in other applications where production of the deficient protein is normally tightly regulated. In the following section, we consider why regulation of therapeutic gene expression is important and, using gene therapy for growth hormone deficiency (GHD) as an example, then discuss how regulation can be achieved in muscle tissue.

\section{Gene therapy for growth hormone deficiency}

In humans, as in rodents, $\mathrm{GH}$ is released from the pituitary gland in an episodic pulse which is controlled by GHreleasing hormone $(\mathrm{GHRH})$, somatostatin and possibly other GH secretagogues (Bluepajot et al. 1998). Many of the features associated with an endogenous GHD, such as low growth rate and serum IGF-I levels, can be corrected in murine models for GHD following injection of GHsecreting modified myoblasts (Al-Hendy et al. 1995) or adenoviral encoded GH cDNA (Hahn et al. 1996). Plasmid vectors have also been used to produce biologically active $\mathrm{GH}$ in differentiated muscle cells, using combinations of viral and muscle-specific transcription for generating optimal levels of this hormone (MacColl et al. 1998). Moreover, serum IGF-I levels and growth rate can be increased following intramuscular injection of plasmids containing either GHRH, or GH coding sequence controlled by a muscle specific promoter (DraghiaAkli et al. 1997, Anwer et al. 1998). Although muscle transcription elements can restrict gene expression to specific muscle fibre types (Skarli et al. 1998), the continuous GH typified by the above methods can cause organ hyperplasia (Hahn et al. 1996, $\mathrm{Ng}$ et al. 1997). Therefore a gene therapy strategy for GHD should ideally possess an inbuilt regulatory element in an effort to mimic the physiological secretion pattern of $\mathrm{GH}$.

\section{Regulated production of growth hormone in muscle}

A controlled release of $\mathrm{GH}$ from striated muscle has been achieved following implantation of engineered human fibrosarcoma cells into nude mice (Rivera et al. 1996) (Fig. 2). These cells express two hybrid proteins, consisting of the ligand binding domains of FKBP12 and FRP, fused with the zinc finger DNA binding domain of ZFBP1 and the transcriptional activation domain of NF- $\mathrm{\kappa B}$ p 65 proteins respectively. The human proteins FKBP12 and FRP form a high affinity complex with the immunosuppressant, rapamycin. Thus, following administration of this drug, the fusion derivatives of FKBP12 and FRP expressed in implanted fibroblasts form a tripartite complex, activating GH expression from a ZFHD1-dependent promoter. A dose-dependent rise in serum $\mathrm{GH}$ is subsequently observed in response to rapamycin administration (Rivera et al. 1996) (Fig. 2).

A similar system, using implanted myoblasts, has been used to modulate serum Epo levels following administration of antibiotic (Bohl et al. 1997) and, as a component of antibiotic regulation is currently being incorporated into the design of viral (Hu et al. 1997) and plasmid (Liang et al. 1996) vectors, this methodology has the potential to deliver an even wider spectrum of biologically active proteins.

\section{Factors influencing the efficacy and safety of gene transfer}

We have discussed the use of MGT for producing several different proteins and methods for regulating therapeutic expression within muscle tissue. However, there are several other important factors which will ultimately determine the success rate of MGT when applied to humans.

\section{Efficiency of gene transfer}

Where MGT has progressed to human trials, the comparison with the corresponding animal studies has not been favourable, as illustrated by recent developments in gene therapy for Duchenne muscular dystrophy (DMD). Implantation of myoblasts expressing a dystrophin coding 
sequence into skeletal muscles of DMD patients was not clinically beneficial to these subjects (Miller et al. 1997), in contrast with a similar application in a murine model for DMD which resulted in long-term expression of a dystrophin cDNA (Floyd et al. 1997).

The reasons for the failure of dystrophin gene transfer in humans are not clear at present. However, there are distinct anatomical differences between humans and rodents in terms of muscle composition, activity and blood/lymphatic microcirculation. These are factors which contribute to the efficiency of gene transfer and ultimately to the effectiveness of these methods in humans. In addition, the age of the muscle used seems to play an important role in efficiency of gene transfer (Wells \& Goldspink 1992, Danko et al. 1997).

\section{Immunogenicity of vectors}

An immune or an inflammatory response directed against viral, cell and plasmid based delivery vectors can greatly limit the efficacy of MGT, as with other methods of gene transfer (Gorecki \& MacDermot 1998). Early studies using an adenoviral based gene therapy to treat cystic fibrosis patients were unsuccessful, due to an inflammatory response directed against the delivery vector in some individuals (Zabner et al. 1993). Recent generations of adenoviral vectors contain no viral protein coding sequences and therefore any observed immune response should not result from de novo viral protein synthesis (Kochanek et al. 1996, Morsy et al. 1998). However, over 40 different adenoviral serotypes have been identified in humans (Scadding \& Gibbs 1994) and pre-existing antibodies in any individual may limit the efficacy of even a 'gutted' adenoviral vector, as this still requires prepackaging in a viral protein coat to facilitate entry into the cell (Kochanek et al. 1996). This is especially relevant where repeated administration of a delivery vector is necessary for an effective treatment.

AAV vectors are derived from human parvoviruses and are intrinsically less immunogenic than adenoviruses (Fisher et al. 1997). However, AAV vectors could be subject to a similar problem as adenoviruses, as a significant proportion of the population will have been exposed to this pathogen (Scadding \& Gibbs 1994) and this could also obstruct re-administration of an AAV vector. Moreover, it may be possible to suppress the specific immune responses which limit the re-administration of viral vectors. For instance, activity of the TH2 subset of T helper cells which block a second administration of recombinant adenovirus virus can be diminished by coadministration with interferon-gamma or interleukin-12 (Yang et al. 1995).

Plasmid based vectors have also been shown to be immunogenic, as these contain immunostimulatory DNA sequences (ISS) which stimulate both macrophage and T lymphocyte based immune responses (Sato et al. 1996, Stacey et al. 1996). These ISS also have an adjuvant property which enhances the effect of DNA vaccines (Roman et al. 1997). However, an immune response directed against these ISS will be undesirable in most of the applications of MGT, as a significant proportion of the population have antibodies to bacterial DNA (DeVlam et al. 1993). Therefore, it must also be established if a patient's immune system will tolerate plasmid based gene transfer into muscle.

\section{Immunogenicity of expressed transgenes}

Although an immune response is the desired consequence of using a DNA vaccine, what is the physical outcome of foreign protein expression in muscle? A common observation following MGT of a heterogeneous protein coding sequence is a peak of expression at 14 days, followed by a decline and then a loss of expression (Wells et al. 1997). Work in this laboratory has shown that an immune response is generated against human factor VII after gene transfer into mouse muscle tissue (Miller et al. 1995). The subsequent loss of expression in muscle tissue results from an elimination of muscle fibres through a cytotoxic $\mathrm{T}$ cell response directed against the immunologically foreign protein (Wells et al. 1997).

The expression of divergent proteins in muscle can also break immune tolerance to the corresponding endogenous protein as, for instance, production of human Epo in mouse muscle activates an $\operatorname{IgG}$ immune response to endogenous Epo (Tripathy et al. 1996). Therefore the primary sequence of a protein must match that of the recipient, to prevent elimination of transfected muscle fibres expressing the protein. Moreover, where a protein is completely absent, as occurs in DMD (Petrof 1998), patients are immunologically naive with respect to the native protein (i.e. dystrophin). This factor could limit the efficacy of a gene therapy for DMD.

\section{Non muscle expression}

The safety of MGT also depends on expression of the introduced gene being restricted to the site where the vector was administered. Recent studies demonstrate that both viral and plasmid vectors can be transported retrogradely to motor neurones innervating the injection site, with subsequent expression of the introduced gene in the neuronal cell body (Haase et al. 1996, Johnson et al. 1998). Although vector uptake by motor neurones might be beneficial in treating MND, it could also result in further damage occurring to the peripheral and central nervous systems and therefore must be investigated further.

The targeting of gene expression to muscle tissue is an important issue and this can be achieved in several ways. First, the use of muscle specific transcription elements in delivery vectors can restrict expression to muscle cells. For instance, the combination of myosin heavy chain promoter and light chain enhancer element used to produce human 
factor VII in muscle tissue (Miller et al. 1995) directs gene expression to muscle fibres in both the fast tibialis anterior and slow soleus muscles in mice (Skarli et al. 1998). Muscle specific expression can also be accomplished by myoblast transfer, as myoblasts will form new muscle fibres at the site of introduction (Pin \& Merrifield 1997). In addition, an even more stringent level for controlling therapeutic gene expression in muscle can be achieved by combining both of the above methods with an element of antibiotic regulation. This method has been utilised in the antibiotic-regulated expression of Epo in muscle, as a human desmin promoter with muscle-specific activity drives expression of an antibiotic binding protein and activates expression of Epo within implanted myoblasts (Bohl et al. 1997).

\section{Discussion}

The examples of MGT discussed in this review demonstrate the potential clinical applications of this methodology and the release of Epo, decorin and IGF-I from muscle show that this tissue can be used as a central site for the production of proteins which have either a local or endocrine effect. However, as with any new drug therapy, the success of MGT depends both on the efficacy and the safety of the methodology used to deliver therapeutic genes into muscle tissue.

The clinical trials for DMD reveal the difficulties inherent in applying MGT to humans. In addition, immune responses to delivery vectors, combined with their tendency to be internalised by neural tissue, are both factors which currently limit the efficiency and safety of MGT. However, the progress currently being made in understanding the mechanisms which underlie vector immunology and transport kinetics may eventually lead to safer methods of gene transfer into muscle. Also, the combination of tissue specific transcription elements with antibiotic regulation can now be used to regulate therapeutic gene expression in skeletal muscle.

Therefore, considering the complex safety and efficacy aspects which must still be resolved, MGT is likely be applied to the most clinically difficult situations first, i.e. those where no effective treatment exists. Motor neurone and Fabry disease are both candidates for MGT and this methodology may also be applied to the treatment of limb ischaemia resulting from peripheral vascular disease, a cause of major morbidity. These and other applications of MGT have now progressed to the clinical trial stage and the results of these studies will give a clearer indication of where MGT will be most effective.

\section{Acknowledgements}

The authors would like to acknowledge Professor I C A F Robinson for suggesting the concept of using muscle as an endocrine tissue and Drs N Marshall and D Gorecki for critical reading of the manuscript. G MacColl is supported by Pharmacia and Upjohn.

\section{References}

Aihara H \& Miyazaki J 1998 Gene transfer into muscle by electroporation in vivo. Nature Biotechnology 16 867-870.

Al-Hendy A, Hortelano G, Tannenbaum GS \& Chang PL 1995 Correction of the growth defect in dwarf mice with nonautologous microencapsulated myoblasts - an alternative approach to somatic gene-therapy. Human Gene Therapy 6 165-175.

Anwer K, Shi M, French MF, Muller SR, Chen W, Liu QS, Proctor BL, Wang JJ, Mumper RJ, Singhal A, Rolland AP \& Alila HW 1998 Systemic effect of human growth hormone after intramuscular injection of a single dose of a muscle-specific gene medicine. Human Gene Therapy 9 659-670.

Apfel SC \& Kessler JA 1996 Neurotrophic factors in the treatment of peripheral neuropathy. CIBA Foundation Symposia 196 98-108.

Barry MA, Lai WC \& Johnston SA 1995 Protection against mycoplasma infection using expression library immunisation. Nature 377 632-635.

Battegay EJ 1995 Angiogenesis-mechanistic insights, neovascular diseases, and therapeutic prospects. Journal of Molecular Medicine $\mathbf{7 3}$ 333-346.

Bluepajot MT, Epelbaum J, Gourdji D, Hammond C \& Kordon C 1998 Hypothalamic and hypophyseal regulation of growth hormone secretion. Cellular and Molecular Neurobiology 18 101-123.

Bohl D, Naffakh N \& Heard JM 1997 Long-term control of erythropoietin secretion by doxycycline in mice transplanted with engineered primary myoblasts. Nature Medicine 3 299-305.

Border WA \& Noble NA 1995 Targeting TGF beta for treatment of disease. Nature Medicine 1 1000-1001.

Cedarbaum JM, Chapman C, Charatan M, Stambler N, Andrews L, Zhan C, Radka S, Morrisey D, Lakings D, Brooks BR, Sanjak M, Pestronk A, Florence J, Mitsumoto H, Szirony K, Bittle L, Neville H, Ringel S, Brinkmann J \& Wittes J 1995 A phase-1 study of recombinant human ciliary neurotrophic factor (rhCNTF) in patients with amyotrophic lateral sclerosis. Clinical Neuropharmacology 18 515-532.

Coleman M, Rabinovsky E, Liu Q, Kattash M, Wang J \& Alila H 1998 Non-viral IGFI gene therapy slows development of motor neuropathy in diabetic mice. (In Press).

Danko I \& Wolff JA 1994 Direct gene-transfer into muscle. Vaccine 12 1499-1502.

Danko I, Williams P, Herweijer H, Zhang G, Latendresse JS, Bock I \& Wolff JA 1997 High expression of naked plasmid DNA in muscles of young rodents. Human Molecular Genetics 6 1435-1443.

Davis HL, Demeneix BA, Quantin B, Coulombe J \& Whalen RG 1993 Plasmid DNA is superior to viral vectors for direct gene transfer into adult mouse skeletal muscle. Human Gene Therapy 4 733-740.

Davis HL, Mccluskie MJ, Gerin JL \& Purcell RH 1996 DNA Vaccine for hepatitis B - evidence for immunogenicity in chimpanzees and comparison with other vaccines. Proceedings of the National Academy of Sciences of the USA 93 7213-7218.

Desnick RJ \& Bishop DF 1995 Fabry Disease and $\alpha$-Galactosidase Deficiency. In The Metabolic Bases for Inherited Disease, pp 2741-2784. Eds Scriver CR, Beaudet AL, Sly WS \& Valle D. New York: McGraw-Hill.

DeVlam K, de Keyser F, Verbruggen G, Vandenbossche M, Vanneuville B, d'Haese D \& Veys EM 1993 Detection and identification of antinuclear autoantibodies in the serum of normal blood donors. Clinical and Experimental Rheumatology 11 393-397.

Draghiaakli R, Li XY \& Schwartz RJ 1997 Enhanced growth by ectopic expression of growth hormone releasing hormone using an injectable myogenic vector. Nature Biotechnology 15 1285-1289. 
Feldman LJ, Tahlil O \& Steg G 1996 Perspectives of arterial gene-therapy for the prevention of restenosis. Cardiovascular Research 32 194-207.

Fischman D 1972 Development of Striated Muscle. In The Structure and Function of Muscle, edn 2, pp 75-142. Ed GH Bourne. New York: Academic Press Inc.

Fisher KJ, Jooss K, Alston J, Yang YP, Haeker SE, High K, Pathak R, Raper SE \& Wilson JM 1997 Recombinant adeno-associated virus for muscle directed gene therapy. Nature Medicine 3 306-312.

Floyd SS, Booth DK, van Deukekom JCT, Day CS \& Huard J 1997 Autologous myoblast transfer: a combination of myoblast transplantation and gene therapy. Basic and Applied Myology 7 241-250.

Gabrilovich DI, Chen HL, Cunninham HT, Meny GM, Nadaf S, Kavanaugh D \& Carbone DP 1996 Production of vascular endothelial growth-factor by human tumours inhibits the functional maturation of dendritic cells. Nature Medicine 2 1096-1103.

Gorecki DC \& MacDermot KD 1997 Gene therapy: panacea or placebo? II. Main applications of gene therapy. Archivum Immunologiae et Therapiae Experimentalis 45 367-374.

Gregoriadis G, Saffie R \& deSouza JB 1997 Liposome-mediated DNA vaccination. FEBS Letters 402 107-110.

Haase G, Kennel P, Vigne E, Akli S, Revah F, Schmalbruch H \& Kahn A 1996 Gene therapy of murine motor neuron disease using adenoviral vectors for neurotrophic factors. Nature Medicine $\mathbf{3}$ 429-436.

Hahn TM, Copeland KC \& Woo SLC 1996 Phenotypic correction of dwarfism by constitutive expression of growth hormone. Endocrinology 137 4988-4993.

Hu SX, Ji W, Zhou YL, Logothetis C \& Xu HJ 1997 Development of an adenovirus vector with tetracycline-regulatable human tumor necrosis factor alpha gene expression. Cancer Research $\mathbf{5 7}$ 3339-3343.

Isaka Y, Brees DK, Ikegaya K, Kaneda Y, Imai E, Noble NA \& Border WA 1996 Gene-therapy by skeletal muscle expression of decorin prevents fibrotic disease in rat kidney. Nature Medicine 2 418-423.

Ishii DN \& Lupien SB 1995 Insulin-like growth factors protect against diabetic neuropathy - effects on sensory nerve regeneration in rats. Journal of Neuroscience 40 138-144.

Johnson IP, Skarli M, Goldspink G, Erabadda P, Coffin RS, Wagstaff M \& Latchman DS 1998 Comparison of plasmid and viral DNA for the transfer of genes to motor neurones. (In Press).

Kochanek S, Clemens PR, Mitani K, Chen HH, Chan S \& Caskey CT 1996 A new adenoviral vector: replacement of all viral coding sequences with $28 \mathrm{~kb}$ of DNA independently expressing both full-length dystrophin and beta-galactosidase. Proceedings of the National Academy of Sciences of the USA 93 5731-5736.

Lepantalo M \& Tukianen E 1996 Combined vascular reconstruction and microvascular muscle flap transfer for salvage of ischemic legs with major tissue loss and wound complications. European Journal of Vascular and Endovascular Surgery 12 65-69.

Liang X, Hartika J, Sukhu L, Manthorpe M \& Hobart P 1996 Novel high expressing and antibiotic controlled plasmid vectors designed for use in gene therapy. Gene Therapy 3 350-356.

MacColl G, Novo J, Marshall N, Goldspink G \& Bouloux P 1998 A method for producing biologically active growth hormone in muscle cells. Journal of Endocrinology 156 (Suppl) OC 20.

McGary EC, Rondon IJ \& Beckman BS 1997 Post-transcriptional regulation of erythropoietin mRNA stability by erythropoietin mRNA-binding protein. Journal of Biological Chemistry 272 8628-8634.

Miller G, Steinbrecher RA, Murdock PJ, Tuddenham EGD, Lee CA, Pasi KJ \& Goldspink G 1995 Expression of factor VII by muscle cells in vitro and in vivo following direct gene transfer - modelling gene therapy for hemophilia. Gene Therapy 2 736-742.
Miller RG, Sharma KR, Pavlath GK, Gussoni E, Mynhier M, Lanctot AM, Greco CM, Steinman L \& Blau HM 1997 Myoblast implantation in Duchenne muscular dystrophy: the San Francisco study. Muscle and Nerve 20 469-478.

Morsy MA, Gu MC, Motzel S, Zhao J, Su Q, Allen H, Franlin L, Parks RJ, Graham FL, Kochanek S, Bett AJ \& Caskey CT 1998 An adenoviral vector deleted for all viral coding sequences results in enhanced safety and extended expression of a leptin transgene. Proceedings of the National Academy of Sciences of the USA 95 7866-7871.

Mumper RJ, Wang JJ, Klakamp SL, Nitta H, Anwer K, Tagliaferri F \& Rolland AP 1998 Protective interactive noncondensing (PINC) polymers for enhanced plasmid distribution and expression in rat skeletal muscle. Journal of Controlled Release 52 191-203.

Ng ST, Zhou JA, Adesanya OO, Wang J, LeRoith D \& Bondy CA 1997 Growth hormone treatment induces mammary gland hyperplasia in ageing. Nature Medicine 3 1141-1149.

Novo FJ, Gorecki DC, Goldspink G \& MacDermot KD 1997 Gene transfer and expression of human alpha-galactosidase from mouse muscle in vitro and in vivo. Gene Therapy 4 488-492.

Ohshima T, Murray GJ, Swaim WD, Longenecker G, Quirk JM, Cardarelli CO, Sugimoto Y, Pastan I, Gottesman MM \& Brady RO 1997 Alpha-galactosidase A deficient mice: a model of Fabry disease. Proceedings of the National Academy of Sciences of the USA 94 2540-2544.

Oyama T, Ran S, Ishida T, Nadaf S, Kerr L, Carbone DP \& Gabrilovich DI 1998 Vascular endothelial growth factor affects dendritic cell maturation through the inhibition of nuclear factor-kappa B activation in hemopoietic cells. Journal of Immunology $1601224-1232$.

Petrof BJ 1998 The molecular basis of activity-induced muscle injury in Duchenne muscular dystrophy. Molecular and Cellular Biochemistry 179 111-123.

Pin CL \& Merrifield PA 1997 Developmental potential of rat L6 myoblasts in vivo following injection into regenerating muscles. Developmental Biology 188 147-166.

Rask CA, Carlsen RC \& Elias KA 1998 Site of action of recombinant human nerve growth factor (rhNGF) in diabetic neuropathy appears to be small sensory neurons in the peripheral nervous system: phase II data support clinical results. Journal of Endocrinology 156 (Suppl) P91.

Rivera VM, Clackson T, Natesan S, Pollock R, Amara JF, Keenan T, Magari SR, Phillips T, Courage NL, Cerasoli F, Holt DA \& Gilman M 1996 A humanised system for pharmacological control of gene expression. Nature Medicine 2 1028-1032.

Roman M, Martin-Orozco E, Goodman JS, Nguyen M-D, Sato Y, Ronaghy A, Kornbluth RS, Richman DD, Carson DA \& Raz E 1997 Immunostimulatory DNA sequences function as T helper-1promoting adjuvants. Nature Medicine 3 849-854.

Rothmann T, Katus HA, Hartong R, Perricaudet M \& Fransz WM 1996 Heart muscle-specific gene-expression using replicationdefective recombinant adenovirus. Gene Therapy 3 919-926.

Sato Y, Roman M, Tighe H, Lee D, Corr M, Nguyen MD, Silverman GJ, Lotz M, Carson DA \& Raz E 1996 Immunostimulatory DNA sequences necessary for effective intradermal gene immunizations. Science 272 352-354.

Scadding JW \& Gibbs J 1994 Neurological disease. In Textbook of Medicine, edn 2, pp 858-982. Eds RL Souhami \& J Moxham. Edinburgh: Churchill Livingstone.

Skarli M, Kiri A, Vrbova G, Lee CA \& Goldspink G 1998 Myosin regulatory elements as vectors for gene transfer by intramuscular injection. Gene Therapy 5 514-520.

Sporn MB \& Roberts AB 1992 Transforming growth factor beta recent progress and new challenges. Journal of Cell Biology 119 1017-1021.

Stacey KJ, Sweet MJ \& Hume DA 1996 Macrophages ingest and are activated by bacterial DNA. Journal of Immunology 157 2116-2122. 
Takeshita S, Pu LQ, Stein LA, Sniderman AD, Bunting S, Ferrara N, Isner JM \& Symes JF 1994 Intramuscular administration of vascular endothelial growth factor induces dose-dependent collateral artery augmentation in a rabbit model of limb ischaemia. Circulation $\mathbf{9 0}$ $228-243$

Tripathy SK, Goldwasser E, Lu MM, Barr E \& Leiden JM 1994 Stable delivery of physiological levels of recombinant erythropoietin to the systemic circulation by intramuscular injection of replication-deficient adenovirus. Proceedings of the National Academy of Sciences of the USA 91 11557-11561.

Tripathy SK, Black HB, Goldwasser E \& Leiden M 1996 Immune responses to transgene encoded proteins limit the stability of gene expression after injection of replication defective adenovirus vectors. Nature Medicine 2 545-550.

Vile RG, Sunassee K \& Diaz RM 1998 Strategies for achieving multiple layers of selectivity in gene therapy. Molecular Medicine Today 4 84-92.

Waine GJ \& McManus DP 1995 Nucleic acids - vaccines of the future. Parasitology Today 11 113-116.

Wang J-M, Zheng H, Sugahara Y, Tan J, Yao SN, Olson E \& Kurachi K 1996 Construction of human factor IX expression vectors in retroviral vector frames optimized for muscle cells. Human Gene Therapy 7 1743-1756.

Wells DJ \& Goldspink G 1992 Age and sex influence expression of plasmid DNA directly injected into mouse skeletal muscle. FEBS Letters 306 203-205.

Wells KE, Maule J, Kingston R, Foster K, McMahon J, Damien E, Poole A \& Wells DJ 1997 Immune responses, not promoter inactivation, are responsible for decreased long-term expression following plasmid gene transfer into skeletal muscle. FEBS Letters 407 164-168.

Wolff JA, Malone RW, Williams P, Chong W, Acsadi G, Jani A \& Felgner PL 1990 Direct-gene transfer into mouse muscle in vivo. Science 247 1465-1468.

Yamaguchi Y, Mann DM \& Ruoslahti E 1990 Negative regulation of transforming growth factor beta by the proteoglycan decorin. Nature 346 281-284.

Yang YP, Trinchieri G \& Wilson JM 1995 Recombinant IL-12 prevents formation of blocking IgA antibodies to recombinant adenovirus and allows repeated gene-therapy to mouse lung. Nature Medicine 1 890-893.

Yang Y, Haeker SE, Su Q \& Wilson JM 1996 Immunology of gene therapy with adenoviral vectors in mouse skeletal muscle. Human Molecular Genetics 5 1703-1712.

Yao SN, Wilson JM, Nabel EG, Kurachi S, Hdachiya HL \& Kurachi K 1991 Expression of human factor IX in rat capillary endothelial cells: toward somatic gene therapy for haemophilia B. Proceedings of the National Academy of Sciences of the USA $\mathbf{8 8}$ 8101-8105.

Yeh P \& Perricaudet M 1997 Advances in adenoviral vectors: from genetic engineering to their biology. FASEB Journal 11 615-623.

Zabner J, Couture LA, Gregory RJ, Graham SM, Smith AE \& Welsh MJ 1993 Adenovirus-mediated gene - transfer transiently corrects the chloride transport defect in nasal epithelia of patients with cystic fibrosis. Cell 75 207-216.

Received 16 July 1998

Accepted 13 October 1998 